УДК $323.2: 321.7$

https://doi.org/10.34142/24130060.2019.19.2.02

\title{
ФЕНОМЕН «СУЧАСНИЙ ПОПУЛІЗМ» У КОНТЕКСТІ РИЗИКІВ І ВИКЛИКІВ ЛІБЕРАЛЬНИХ ДЕМОКРАТІЙ ХХІ СТОЛІТТЯ
}

\begin{abstract}
А.О. Житко
Харківський національний педагогічний університет імені Г.С. Сковороди

У статті здійснюється спроба дескрипиії та аналізу новітніх західних $i$ вітчизняних теоретичних конструкиій, щэодо пізнання природи та сутності феномену «сучасний популізм». Акиентовано увагу на тому, щзо «глобальний успіх популістів» у XХI столітті створює реальну загрозу ліберально-демократичним ичінностям - індивідуальній свободі, плюралізму, свободі слова, вільним виборам тощо. Охарактеризовано ключові чинники, щуо спровокували «вибух популізму», зокрема, домінування в суспільно-політичних настроях сучасного вибория відчуттів "розчарування», "розгубленості», «невизначеності» та ін. Автором здійснюється спроба пошуку ефективної стратегій протидї «агресивному популізму» в контексті медіатизації сучасних політичних
\end{abstract} проиесів.

Ключові слова: популізм, сучасний популізм, ліберальні демократі, ліберальнодемократичні иүінності, демократичні ризики, світовий порядок, медіатизація політики.

\section{ФЕНОМЕН «СОВРЕМЕННЫЙ ПОПУЛИЗМ» В КОНТЕКСТЕ РИСКОВ И ВЫЗОВОВ ЛИБЕРАЛЬНЫХ ДЕМОКРАТИЙ ХХІ ВЕКА}

\begin{abstract}
А.А. Житко
В статье осуществляется попытка дескрипции и анализа новейших западных $u$ украинских теоретических конструкиий, относительно познания природы и сущности феномена «современный популизм». Акиентировано внимание на том, что «глобальньии успех популистов» в XXI веке создаёт реальную угрозу либерально-демократическим иенностям - индивидуальной свободе, плюрализму, свободе слова, свободным выборам и т.д. Охарактеризовано ключевые факторы, которые спровочировали «взрыв популизма», в частности, доминирование в сочиильно-политических настроениях современного избирателя чувств «разочарования», «растерянности», «неопределённости» и т.n. Автором осуществляется попытка поиска эффективной стратегий противодействия «агрессивному популизму» в контексте медиатизации современных политических прочессов.
\end{abstract}

Ключевые слова: популизм, современный популизм, либеральные демократии, либерально-демократические ценности, демократические риски, мировой порядок, медиатизачия политики. 


\section{THE PHENOMENON OF «MODERN POPULISM» IN THE CONTEXT OF THE RISKS AND CHALLENGES OF THE LIBERAL DEMOCRACIES OF THE XXI CENTURY}

\section{A. Zhytko}

In the article attempts of description and analyze of research studies are undertaken, which are recognized in the modern scientific world as "strong points》 in the study of the phenomenon of populism, in particular - G. Ionesk, E. Gellner, D. Bell, M. Kenovan, P. Tagart, E. Laclau, I. Me, I. Sorel et other, and the latest Western and domestic theoretical constructs, which lead to the knowledge and the nature and essence of the phenomenon of "modern populism», namely - Z. Bauman, W. Beck, F. Venturi, A. Grimimal-Buss, K. Davyst, J. Judis, R. Itwell, J.-V. Muller, T. Snyder, etc.; T. Andrushchenko, V. Bebyk, S. Datsyuk, I. Kiananka, G. Kuts, O. Lisnichuk, L. Matlai, I. Pobochi, T. Pryadko, T. Rad, O. Yarosha and others. It is determined that the overwhelming majority of modern researchers express a consolidated position on the complexity of definition («populism is the phenomenon dispersed, i.e. it is a component of many political phenomena, embodied in various ideological forms and political strategies») and a huge variety of manifestation of modern populism D. Trump (USA), Brexit (UK), Yellow Vest Movement (France), Five Star Movement (Italy), Podemos (Spain), G. Wilders (Netherlands), V. Orban (Hungary), R. Erdogan (Turkey), etc.

Attention is drawn to the fact that the "global success of populists» in the 21st century creates a real threat to liberal-democratic values - individual freedom, pluralism, free speech, free elections, etc. The key factors that provoked «the outburst of populism» are characterized, in particular, the dominance of the contemporary voter in the socio-political moods of feelings of "disappointment», "confusion», "uncertainty" and others. The author attempts to find effective strategies for counteracting "aggressive populism» in the context of the mediation of contemporary political processes, in particular, the formation of critical thinking and media literacy of the modern voter. It is stated that the "wave» of populism also seized the political space of modern Ukraine, in which the mediation of political processes created a new format of communication between voters and politicians, which, in fact, attested to the results of recent presidential and parliamentary election campaigns.

Keywords: populism, modern populism, liberal democracies, liberal-democratic values, democratic risks, world order, political mediation.

Постановка проблеми. Як зазначив провідний теоретик сучасності Зигмунд Бауман «У добу нової й новітньої історії ми звикли ототожнювати порядок 3 «контролем над ситуацією». Саме цього відчуття «контролю над ситуацією», обгрунтованого або часто ілюзорного, нам бракує понад усе» (Бауман, 2008, с. 48). Численні військово-політичні конфлікти, перманентна загроза тероризму, системні фінансово-економічні кризи, некерованість міграційних процесів, зростаючий рівень безробіття та бідності, незворотні зміни клімату та масштабні екологічні катастрофи - все це маркери «Нового світового безладу» (Бауман, 2008, с. 48), що характеризують реальність ХХІ століття в категоріях «неконтрольованості», «некерованості», 
«непрогнозованості». Як влучно коментує Річард Хаас: «Ситуація в багатьох регіонах світу, більше нагадує новий світовий безлад. ... Гірше за все, загальна тенденція вказує на подальше зростання безладу» $(2016$, с. 13) і окремо, до списку викликів XXI століття додає «стрімкий злет популізму», при цьому акцентуючи - «Популізм і націоналізм сьогодні вочевидь знаходяться на підйомі. Ми присутні при і спостерігаємо на власні очі широко розповсюджене несприйняття глобалізації та міжнародної співпраці, 3 яких проростають сумніви в цінностях попередніх позицій і попередньої політики» (Хaаc, 2016, с. 10).

Беззаперечно, «політики-популісти «глобалізаційної доби» відверто спекулюють на «соціально гострих темах» - бідності, безробітті, тероризмі, війнах, мігрантах» (Калюжна, 2017, с. 85), і за допомогою медіатизації сучасної політики, пропонують виборцям «райдужні» картини майбутнього, які апріорі неможливо втілити в реаліях сучасної політики та економіки, або пропонують «готові рецепти» 3 минулого, які «вдало спрацювали» в певний час i за певних умов, проте вочевидь виявляться марними в реаліях сьогодення. «Популізм за рахунок мас-медійних технологій набуває якості віртуальних політичних дій, бо повідомлення у мас-медіа і соціальних мережах стають замінниками конкретних політичних дій і рішень. Як медіареальність стає симулякром політичної реальності, так і медіа-повідомлення про політику стає симулякром (медійною замінною) існуючої політичної реальності» (Амельченко, 2019, с. 7), - як наслідок, - поглиблення існуючих та продукування нових кризових явищ, зростання «некерованості» та «непрогнозованості» суспільно-політичними процесами, - «дуже часто популістський лідер шукає швидкі та прямі вирішення соціальних проблем, які згодом призводять до гірших трагедій і катастроф» (Матлай, 2015, с. 117).

Слід зазначити, враховуючи масштабність і динамічність поширення «політичного тренду популізм» в XXI столітті, наукове співтовариство, повинно сконцентрувати увагу на пошуку новітніх теоретичних конструкцій, вдосконаленню методологічного інструментарію та розробці стратегій 
ефективної протидії «агресивному популізму», що видається особливо актуальним в контексті глобальних ризиків та викликів Новітнього часу.

Аналіз актуальних досліджень. Наприкінці XX - початку XXI століття, провідні науковці суспільно-політичного дискурсу презентують дослідницькі розробки, які визнано в сучасному науковому світі - «опорними точками» при досліджені феномену популізм, зокрема, - Г. Іонеск та Е. Гелнер «Популізм: його значення і національні характеристики» (1969), Д. Белл «Популізм і елітизм: політика в епоху рівності» (1992), М. Кенован «Популізм» (1981), П. Таггарт «Популізм» (2000), Е. Лаклау «Причини популізму» (2005), Ф. Паніцци «Популізм і дзеркало демократії» (2005), I. Мені та I. Сорель «Демократія під призмою популізму» (2007) та інші.

Втім, теоретико-методологічні креслення, щодо феномену популізм набувають більш вираженого концептуального оформлення в дослідницьких проектах провідних експертів сучасності - 3. Баумана, У. Бека, Б. Бекера, К. Вейланда, Ф. Вентурі, К. Верніке, Дж. Гарсія, М. Годвіна, А. ГржималаБюссе, К. Дейвікст, Дж. Джудіса, У. Еко, Б. Еммотта, Д. Зіблатт, Р. Ітвелла, М. Казіна, Дж. Кейтеба, Р. Кеннета, Е. Колба, Е. Крейг, М. Круза, С. Левіцкі, К. Мадде, Д. Макре, Я.-В. Мюллера, Е. Папареллі, Д. Родріка, С. Сабала, Т. Снайдера, Х. Торребланка, А. Турена, Ф. Фукуями, Р. Хофстартера, Р. Хурадо та багатьох інших.

У вітчизняному суспільно-гуманітарному дискурсі проблематика феномену «популізм» перебуває у дослідницькому фокусі - Т. Андрущенко, О. Бабкіної, В. Бебика, С. Бульбенюк, К. Ващенка, Д. Видріна, Д. Гаврилюка, М. Головатого, I. Горбатенко, С. Дацюк, М. Дем’яненка, С. Денисюк, О. Дубини, І. Кіянки, В. Корнієнка, В. Кривошеїна, Г. Куц, Н. Латигіної, О. Ліснічук, Л. Матлай, С. Мигаль, О. Новакової, М. Остапенко, І. Побочия, А. Погорєлової, В. Полторака, Т. Прядко, Т. Радь, Н. Рєзанової, О. Стогова, О. Яроша та інших.

Виходячи з вище зазначеного, мета статті - здійснити дескрипцію та проаналізувати новітні теоретичні конструкцій щодо пізнання природи та 
сутності феномену «сучасний популізм»; визначити його вплив на ліберальні демократії XXI століття.

Виклад основного матеріалу. Як констатує політолог Т. Радь «Амплітуда вживання терміну «популізм» така велика, що становить труднощі для виведення наукової дефініції» (Радь, 2009, с. 290), проте, робить сміливу спробу згрупувати всі дефініції за певними видовими ознаками, - результатом дослідницької рефлексії вітчизняного науковця стає наступне визначення, - популізм - це: 1) ідейна течія, що відображає масові настрої, прагнення людей; 2) політичний рух, який прагне здобути владу для блага усього народу, який виникає в результаті реакції суспільних елементів на стрімкі економічні, соціальні, політичні і культурні зміни 3 метою реставрації (або адаптації) простих традиційних форм і цінностей; 3) певний тип ідеології, що підтримує ідею сильної держави за прямої участі народу в державному управлінні та при цьому враховує національні суспільні традиції, та їх специфічні інтереси; 4) різновид поведінки політика, схильність завойовувати популярність, визначити свою громадськополітичну діяльність, використовуючи прості, зрозумілі населенню аргументи і пропозиції; 5) сукупність гасел і дій, а також форм, методів та технологій, що застосовуються політичними діячами 3 метою здобуття i поглиблення підтримки з боку широких народних мас (Радь, 2009, с. 289293). На схожу теоретико-методологічну платформу спирається й український дослідник О. Ярош, який пропонує визначити популізм як «явище дисперсне, тобто воно є складовою багатьох політичних феноменів, утілюється в різноманітні ідеологічні форми та політичні стратегії) (Ярош, 2002, с. 22). Зауважимо, подібний когнітивний підхід створює перспективи для подальших дискусійних конструкцій в сучасному політологічному просторі, до того ж, беззаперечно, є успішною спробою наблизитись до розуміння природи та сутності феномену «популізм».

Втім, для розширення горизонтів дослідження феномену «сучасний популізм» варто звернутись до міркувань британського науковця П. Таггарта, 
який проблемне поле феномену «популізм» розглядає в рамках визначення ключових ознак, зокрема: 1) негативне сприйняття представницької політики; 2) часте звертання до ідеалізованої «середини», в якому все: суспільство, політика, економіка - відображає цінності й вірування «звичайних» людей; 3) «нестача основних цінностей»; 4) популістський рух зазвичай активізується під час криз, тобто тоді, коли соціальні, економічні й політичні структури знаходяться в складному становищі; 5) популістські рухи недовготривалі, тобто вони втрачають своє «обличчя», як тільки стають частиною тих структур, проти яких вони так рішуче виступали; 6) природа популізму залежить від національного контексту, в якому проявляється популізм (Taggart, 2000). На думку американського експерта Т. Снайдера, вихідним пунктом у пізнанні феномену «нового популізму XXI століття», стає дескрипція і аналіз основних характерних рис: 1) за ним (популізмом) завжди стоять потужні цифрові технології; 2) популізм зневажає державу і, головне, 3) популізм заперечує наявність по-справжньому серйозних проблем, підмінюючи їх менш важливими, але більш хайповими (Чунихина, 2019).

Відтак, констатуємо, переважна більшість сучасних дослідників висловлює консолідовану позицію «про складність дефініції та величезну різноманітність проявів популізму» (Кіянка, 2018) - Д. Трамп (США), Brexit (Великабританія), «Рух Жовтих Желетів» (Франція), Й. Хайдер (Австрія), «Рух П’ять Зірок» (Італія), «Подемос» (Испанія), Г. Вілдерс (Нідерланди), В. Орбан (Угорщина), П. Генсон (Австралія), Р. Ердоган (Туреччина), Р. Kорреа (Еквадор), А. Фухіморі (Перу), Р. Мугабе (Зімбабве) та багато інших прикладів. Разом $з$ тим, спільною є й думка про те, що - в умовах «глобального успіху популістів» існує реальна загроза ліберальнодемократичним цінностям - індивідуальній свободі, плюралізму, свободі слова, вільним виборам тощо. Зокрема, професор Стенфордського університету А. Гржимала-Бюссе, наголошує: «сучасний популізм став реальною загрозою для ліберальних демократій ... через зменшення 
терпимості, зневаги до опозиції, нехтування свободою слова, підрив офіційних інститутів демократії, знецінення неформальних цінностей, які покладено в основу демократі» (Гржимала-Бюссе, 2018). Еліанора Крейг висловлює переконання, що європейські політики-популісти здатні зруйнувати ліберальний світовий порядок: «Європа - породження ліберальної демократії і мультілатерізма - в теперішній час є континентом, політичному фундаменту якого загрожує зростаючий популізм. Політична нетерпимість і геополітична напруга можуть призвести до руйнування ліберального світового порядку. ... може призвести до дезінтеграції існуючого стану через зростання незадоволеності і негативного сприйняття глобалізованого суспільства» (Крейг, 2019). А в дослідженні Я.-В. Мюллера «Що таке популізм?», критично аналізуючи феномен сучасного популізму, на прикладі американських та європейських виборчих компаній останніх років, автор робить висновок: «Небезпека полягає в популізмі - деградованій формі демократії, яка обіцяє втілити в життя найвищі демократичні ідеали («Правити повинен народ!). Іншими словами, небезпека походить з середини демократичного світу - політичні діячі, що несуть загрозу, говорять мовою демократичних цінностей. Той факт, що в результаті ми отримуємо відверто антидемократичну форму правління, повинен занепокоїти нас усіх» (Мюллер, 2018, с. 12). На демократичних ризиках акцентують увагу й провідні західні експерти з питань сучасної політики Р. Ітвелл і М. Годвін, в теоретичних інтерпретаціях яких ключ до розуміння феномену «популізм» закодовано в чотирьох «великих D»: 1) Distrust (недовіра) - елітитська за своєю природою, демократія породжує недовіру між населенням і політичним класом; 2) De-alignment (вирівнювання) - це в свою чергу послаблює зв’язки між політичними партіями та населенням, тобто зменшує легітимність представництва; 3) Deprivation (обмеження) - як наслідок, громадянин почуває, що не має можливості впливати на політичні та економічні процеси, а тому вдаються до політики незгоди; 4) Destruction of identity (знищення особистості) - за таких умовах зростає страх втрати 
ідентичності політично - організованої спільноти. (Eatwell \& Goodwin, 2018, p. 4-8).

Як бачимо, з аргументації сучасних науковців «процвітання сучасного популізму пов'язано з тим, що сила популізму є тим більшою, чим менше державна політика здатна давати відповіді на питання, які ставить перед нею радикально оновлений світ» (Бек, 2011, с. 26), «очевидним видається факт того, що «сучасний популізм» $\epsilon$ «продуктом глобалізаційної доби», а його специфічні риси - «агресивна експансія», «парадоксальність», «багатоликість» - обумовлені «новою нормальністю» - «новою реальністю» притаманною новому суспільству (Калюжна, 2017, с. 86). В масовій свідомості XXI століття домінантними рисами стають відчуття «розгубленості», «розчарування», «невизначеності», «некерованості» та «непрогнозованності», і як резюмує 3. Бауман - «Одним словом, сьогодні, схоже, ніхто не контролює ситуацію. Гірше того - не зрозуміло, що означає «контролювати ситуацію» в сучасних умовах» (Бауман, 2008, с. 49); в цьому контексті висловлюється й П. Таггарт: «Глобалізація, кризи економічного росту та інші структурні обставини призводять до розчарування в певних суспільних групах, змушуючи їх приєднатись до популістичної політики» (Taggart, 2000, p. 20).

В умовах «Нового світового безладу», як окремі громадяни, так i держави в цілому, гостро відчувають «безпорадність», «невизначеність», «непередбачуваність», щодо майбутнього світового порядку, цим емоційним станом «глобальної панічної атаки» неминуче скористались сучасні політики-популісти, маніпулюючи суспільно-політичними настроями вони змогли сконцентрувати «народний гнів» та перекласти всю відповідальність за «існуючі негаразди» на плечі правлячої політичної еліти - «популісти відкидають роль громадянського суспільства, перекладаючи головну відповідальність на умовні «старі еліти», і в такий спосіб намагаються переконати громадян, що прогрес неможливий доки ці еліти залишаються при владі (Mudde, 2004, p. 543). Як стверджує вітчизняний експерт I. Кіянка: 
«коли популізм апелює до суспільних настроїв, тоді власне появляється спроба підлаштуватися під стереотипи масової свідомості і тоді популізм стає засобом завоювання влади. А підвладна маса потребує від влади, поперше, опіки, турботи, догляду, патерналістського забезпечення базового комфорту - фізіологічного і психологічного. По-друге, встановлення чи дотримання порядку. По-третє, надання сенсу колективному та індивідуальному існуванню, творенню привабливої спільної ідеї. Хоча це є своєрідна ілюзія, але без неї суспільство не може нормально існувати, інакше воно впадає у стан аномії» (Кіянка, 2017, с. 70). В грунтовному дослідженні Дж. Джудіса «Великий вибух популізму. Як економічна криза змінила світову політику», автор наголошує: «До факторів, що сприяють успіхові популістських партій, належить усвідомлення людьми того факту, що панівні політичні норми починають суперечити їх власним надіям, страхам i турботам. Популісти виголошують у гаслах ці зневажувані побоювання і будують на них власну політику, нацьковуючи народ на еліту, яка не погоджується на компроміси. Діючи так вони стають каталізатором політичних змін. ... популісти збурюють хвилі. Вони подають сигнал, що панівна політична ідеологія не працює i потребує налагодження, що стандартний світогляд зруйновано» (Джудіс, 2017, с. 19).

Вочевидь, «хвиля» популізму захопила й політичний простір сучасної України, в якій медіатизація політичних процесів створила новий формат комунікації між виборцем і політиками, що власне, засвідчили результати останніх президентських та парламентських виборчих компаній. Важливо наголосити, якщо західним ліберальним демократіям (США, Великобританія, Франція та ін.) вкрай складно протистояти агресивним проявам «сучасного популізму», то для сучасної України, перевантаженої військово-політичним конфліктом з Росією, «хронічними» політичними та соціально-економічними кризами та іншими надгострими проблемами, взагалі, постає питання збереження основ державності на основі ліберально-демократичних цінностей. 
Висновки i перспективи подальших досліджень. «Панацеї від популізму не існує і немає ніякої покрокової інструкції, як перемогти популістів. Проте ми все ж не повністю дезорієнтовані і безпорадні» (Мюллер, 2018, с. 19), а відтак, на нашу думку, головними запобіжниками проти «сучасного популізму» $є$ підвищення рівня політичної культури і громадянської освіти, формування критичного мислення і медіаграмотність сучасного виборця, адже дескрипція і аналіз новітніх західних та вітчизняних досліджень присвячених феномену «сучасного популізму» дозволяє зафіксувати ключову тезу - існує реальна загроза дисфункції ліберальних демократій в наслідок «вибуху популізму» XXI століття.

\section{ЛІТЕРАТУРА}

1. Амельченко, Н., 2019. Популізм у контексті кризи класичних ідеологій і виникнення мас-медійнихтехнологій політики. В: Києво-Могилянська академія та Інститут громадянської освіти імені Сергія Рябова. Популізм $і$ громадянське суспільство: межі перетину: Науково-практична конференція. Київ, Україна, 24 Березень 2019. Київ.

2. Бауман, 3., 2008. Глобалізація. Наслідки для людини і суспільства. Переклад 3 англійської І. Андрущенка. Київ: Вид. дім «Києво-Могилянська академія».

3. Бек, У., 2011. Влада $і$ контрвлада у добу глобалізації. Нова світова політична економія. Переклад з німецької О. Юдіна. Київ: Ніка-Центр.

4. Гржимала-Бюссе, А., 2018. Чому популізм перемагає в Україні та світі. Інтерв'ю $з$ професором політології Стефорда. [online] (Останнє оновлення 27 Лютий 2018) Доступно: https://nv.ua/ukr/world/populizm-peremahaje-tomu-shcho-vibortsjamostohidli-partiji-ta-jikh-lideri-jaki-do-nikh-ne-doslukhajutsja-intervju-z-profesorompolitolohiji-stenforda-2454303.html [Дата звернення 20 Лютий 2019].

5. Джудіс, Дж. Б., 2017. Великий вибух популізму. Як економічна криза змінила світову політику. Переклад з англійської Н. Палій. Харків: КСД.

6. Калюжна, Ю. І., 2017. Популізм, як політико-культурний феномен сучасної світової політики. Сучасне суспільство, 2 (14), с. 80-87.

7. Кіянка, I., 2017. Публічна політика і популізм у XXI столітті: приклад США та Франції. Вісник Дніпропетровського університету, 1, с. 63-72.

8. Кіянка, I., 2018. Популізм як виклик публічному управлінню: історичний аспект. Демократичне врядування, [online] Доступно: http://www.lvivacademy.com/vidavnitstvo_1/visnyk21/fail/Kijanka.pdf [Дата 16 лютого звернення 2019].

9. Крей, Э., 2019. Рост популизма и долгов. Зеркало недели, 13 Апрел. [online] https://zn.ua/gazeta/issue/1196 [Дата звернення 20 квітня 2019]. 
10. Матлай, Л. С., 2015. «Podemos» («Ми можемо»): нова партія «невдоволених» владою чи перехід до багатопартійної системи в Іспанії? Сучасне суспільство, 2 (8), с. 110118.

11. Мюллер, Я. В., 2018. Что такое популизм? Перевод с английского А. Архиповой. Москва: Издательский дом Высшей школи экономики.

12. Радь, Т., 2009. Теоретичні засади популізму. Науковий Вісник Ужгородського університету. Політологія, Соиіологія, Філософія, 13, с. 289-293.

13. Хаас, Р., 2016. Мировой беспорядок. Американская внешняя политика и кризис старого порядка. Перевод с английского В. Желнинов. Москва: АСТ.

14. Чунихина, С., 2019. Новый украинский популизм. О чем сказал и промолчал Владимир Зеленский в своїй инаугурационной речи [online] (Последнее обновление 20 Май 2019) Доступно: https://focus.ua/opinions/429431-novyj-ukrainskij-populizm-ochemskazal-i-promolchal-vladimir-zelenskij-v-svoej-inauguracionnoj-rechi.html [Дата звернення 24 Май 2019].

15. Ярош, О., 2002. Політичний популізм: теорія і практика передвиборного «флірту». Контекст, 2, с. 21-25.

16. Eatwell, R. \& Goodwin, M., 2018. National Populism: The Revolt Against Liberal Democracy. London: Pelican.

17. Mudde, C., 2004. The Populist Zeitgeist. Government \& Opposition. London. p. 541-563.

18. Taggart, P., 2000. Populism. Buckingham PA: Open University Press.

\section{Інформація про автора}

Житко Андрій Олександрович - аспірант кафедри політології, соціології і культурології Харківського національного педагогічного університету імені Г.С. Сковороди; e-mail: zhytkoscience.2019@gmail.com; ORCID: http://orcid.org/0000-0002-7003-5562.

Стаття надійшла до редакції: 04.11.2019 р. $\quad$ Прийнята до друку: 25.11.2019 p. 